\title{
Financial Reporting Quality And Acquisition Profitability: Evidence From Korea
}

\author{
Youngtae Yoo, Yonsei University, Korea \\ Joohyun Lim, Yonsei University, Korea \\ Jinho Chang, Yonsei University, Korea
}

\begin{abstract}
In this paper, we examine the association between financial reporting quality and acquisition profitability in a sample of 282 acquisitions in South Korea between 2001 and 2011. Using the accruals quality measure developed by Dechow and Dichev (2002) and McNichols (2002), we find that firms with high-quality financial reporting make more profitable acquisitions, as measured by the bidder's announcement returns. In addition, we find that the importance of financial reporting quality increases in firms with poor information environments.
\end{abstract}

Keywords: Financial Reporting Quality; Acquisition Profitability; Information Environment

\section{INTRODUCTION}

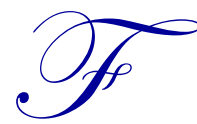

inancial reporting quality has a profound influence on managerial decision-making, particularly in the areas of investment. Prior studies suggest that high-quality financial reporting may increase investment efficiency (e.g., Bushman and Smith, 2001; Healy and Palepu, 2001; Biddle and Hilary, 2006; Biddle et al., 2009). They posit that the association between financial reporting quality and investment efficiency relates to a reduction in information asymmetry between firms and external suppliers of capital because transparent accounting reduces both adverse selection and moral hazard. For example, high-quality financial reporting may allow constrained firms to attract capital by making their positive net present value (NPV) projects more visible to investors and reducing adverse selection in the issuance of securities. In addition, high-quality financial reporting may curb managerial incentives to engage in value-destroying activities such as empire building in firms with excess capital. High-quality financial reporting improves contracting, prevents inefficient investment, and increases investors' ability to monitor managerial investment decisions.

Acquisitions are among the largest and most readily observable forms of corporate investment. Investments in this form tend to intensify the conflicts of interest inherent between managers and shareholders in large public companies (Berle and Means, 1933; Jensen and Meckling, 1976). It is also well recognized that managers do not always make shareholder value-maximizing acquisitions; instead, they may extract private benefits at the expense of shareholders. Jensen (1986) argues that managers pursue perquisite consumption from empire building. He predicts that firms with abundant cash flows are more likely to make value-destroying acquisitions rather than excess payouts to shareholders. ${ }^{1}$ Morck, Shleifer, and Vishny (1990) identify several types of acquisitions that can yield substantial benefits to managers at the expense of shareholders.

In this paper, we investigate the effects of high-quality financial reporting on information asymmetry between managers and shareholders and on management investment decisions, focusing on acquisition. If shareholders could monitor and control the acquisition decisions of managers based on high-quality financial reports, acquisitions that reduce shareholder value and increase personal benefits to managers would be disallowed, and acquisition investment profitability would be higher.

\footnotetext{
${ }^{1}$ The research of Lang, Stulz, and Walkling (1991) also provides evidence supporting this assertion.
} 
We define financial reporting quality as the degree to which financial reporting conveys precise information about a firm's operation. We use a measure of accruals quality developed by Dechow and Dichev (2002) and McNichols (2002) as a proxy for financial reporting quality. This measure is based on the idea that accruals have a shifting or adjusting effect on the recognition of cash flows over time. Adjusted earnings is a superior measure of firm performance that has been used extensively in earlier literature. The use of accruals quality as a measure depends on the fact that accruals are assumptions and estimates of future cash flows that are more representative of future cash flows when the magnitude of error in estimation of accruals is lower. We define acquisition efficiency (profitability) of investment decisions as the acquirer's 3-day cumulative abnormal returns (CARs) around the initial acquisition announcement date, following the procedure of Francis and Martin (2010). This definition captures the market's expectation of both ex ante investment selection and ex post decision-making.

We study the relation between financial reporting quality and acquisition investment efficiency in a sample of 282 completed acquisitions in South Korea provided by S\&P Capital IQ, a data supplier, during the sample period of 2001 to 2011. We find a positive association between the financial reporting quality of the acquiring firm and larger announcement returns. In addition, we find a stronger association between high accounting quality and acquisition investment efficiency in a low-quality information environment, as measured by lack of analyst following. This result suggests that the importance of financial reporting quality increases in firms with poor information environments, and that information environments may be interchangeable with financial reporting quality in terms of their association with acquisition profitability.

Our findings contribute to a growing body of literature on the relations between financial reporting quality and investment decisions (e.g., Bens and Monahan, 2004; Biddle and Hilary, 2006; Bushman et al., 2006; Betty et al., 2008; Beatty et al., 2008; Hope and Thomas, 2008; McNichols and Stubben, 2008; Biddle et al., 2009; Francis and Martin, 2010). Our results extend and generalize the results of prior studies by using acquisition profitability as a measure of investment efficiency instead of over- or underinvestment, which has been frequently used in earlier studies. This relationship between financial reporting quality and acquisition efficiency has seldom been explored in prior research. ${ }^{2}$ Our study is also related to those of Chen et al. (2007) and Francis and Martin (2010), who document the positive association between monitoring systems and expected acquisition profitability. This association is more pronounced for bidders with high ex ante agency costs.

The remainder of the paper proceeds as follows. The next section reviews prior literature and develops our hypotheses. Section 3 describes the sample and research design. Section 4 presents the empirical results. Section 5 concludes.

\section{RELATED RESEARCH AND HYPOTHESIS DEVELOPMENT}

\subsection{The Effect of Information Asymmetry between Managers and Outside Suppliers of Capital on Investment Efficiency}

Agency theory describes the natural conflict between managers and shareholders. The conflict arises because managers choose actions to maximize their own utility. The conflict is caused by information asymmetry between managers and outside suppliers of capital. Information asymmetry between managers and shareholders can reduce capital investment efficiency by giving rise to imperfections such as moral hazard and adverse selection.

Moral hazard models suggest that managers will invest in inefficient projects such as negative NPV projects when information asymmetry exists between principal and agent. According to Berle and Means (1933) and Jensen and Meckling (1976), managers maximize their personal welfare by investing opportunistically at the expense of shareholders' interests. Jensen (1986) suggests that managers have incentives to invest beyond their optimal size for the purpose of empire building rather than making excess payouts to shareholders. In addition, Shleifer and Vishny (1989) describe the incentive of managers to make manager-specific investments that make it

\footnotetext{
${ }^{2}$ McNichols and Stubben (2011) and Raman, Shivakumar, and Tamayo (2008) also consider accounting quality and acquisitions. These studies examine the effects of the target's accounting information quality. However, our paper focuses on the quality of financial reporting of acquiring firms rather than that of target firms.
}

1738 Copyright by author(s) $\underline{\text { Creative Commons License CC-BY }}$

2013 The Clute Institute 
costly for shareholders to replace them, allow them to extract higher wages and larger perquisites from shareholders, and enable them to obtain more latitude in determining corporate strategy. Models of adverse selection in the research of Myers and Majluf (1984) suggest that if managers are better informed than investors about a firm's prospects, they will try to sell overpriced securities in order to raise capital. If managers are successful, they may overinvest these proceeds. However, in response, rational investors will increase the cost of capital, which may lead to ex post underinvestment. Therefore, adverse selection also leads to inefficient investment on the part of managers.

\subsection{The Effect of Financial Reporting Quality on Investment Efficiency}

Monitoring systems are required to mitigate managerial opportunistic investment decision-making under conditions of information asymmetry between managers and outside suppliers of capital. Jensen (2000) emphasizes the importance of monitoring systems to curb managerial incentives to overinvest, and Watts and Zimmerman (1983, 1986) and Ball (1989) consider accounting to be a part of the firm's controlling mechanism. In addition, Bushman and Smith (2001) present an overview of the large body of literature that describes financial accounting reporting as an important source of information used by shareholders and others to monitor managers. Other recent literature suggests that financial reporting quality can affect investment efficiency, emphasizing the ability of monitoring to mitigate information asymmetry between managers and shareholders.

Biddle and Hilary (2006) examine the relations between accounting quality and firm-level capital investment efficiency. They provide evidence that high-quality accounting enhances investment efficiency by reducing information asymmetry between managers and outside suppliers of capital. This effect is stronger in economies dominated by stock markets than in those dominated by creditors. Biddle et al. (2009) find a positive association between high-quality financial reporting and lower overinvestment and underinvestment. They argue that better financial reporting can increase capital by reducing adverse selection and creating positive NPV projects. Alternatively, better financial reporting can curb managerial incentives to engage in value-destroying activities such as empire building in firms with ample capital. It can also enhance investors' ability to monitor managerial investment decisions. McNichols and Stubben (2008) document that firms that misrepresent their financial status make investments that are substantially larger than optimal size. This finding suggests that financial reporting quality can influence internal decision-making.

Hope and Thomas (2008) test the agency cost hypothesis in the context of geographic earnings disclosures. They find that because nondisclosure of geographic earnings hinders the ability of shareholders to monitor managers, managers are more willing to engage in empire building, despite the fact that it reduces firm value. Francis and Martin (2010) investigate the association between timely loss recognition and acquisition investment decisions. They predict that accounting conservatism reduces information asymmetry between managers and shareholders, thus playing a strong governing role in the monitoring of managerial performance and leading to more profitable acquisitions. Chang et al. (2009) show that firms with better financial reporting have more flexibility to issue capital. High-quality financial reporting reduces adverse selection costs, which is associated with investment efficiency and reduced external financing costs. In addition, the likelihood that a firm will obtain excess funds because of temporary mispricing is also reduced. In sum, prior studies provide evidence that high-quality financial reporting increases shareholder ability to monitor managerial investment activities, thereby enhancing investment efficiency.

\subsection{Hypothesis Development}

In this study, we investigate the relationship between financial reporting quality and investment efficiency, focusing on acquisition. We predict that the relationship between financial reporting quality and investment decision profitability is salient in the context of acquisitions under conditions of information asymmetry between managers and outside suppliers of capital for the following reasons.

First, acquisitions are among the largest and most readily observable forms of corporate investment. Second, investment in the form of acquisition tends to intensify agency conflicts between managers and shareholders in public companies (Berle and Means, 1933; Jensen and Meckling, 1976). Jensen (1986) and Blanchard et al. (1994) document that managers pursue perquisite consumption and empire building rather than making excess payouts to shareholders by making value-decreasing acquisitions. Morck et al. (1990) suggest that acquisition can provide 
personal benefits to managers such as enabling managers to diversify the risk of their own human capital, and improving their job security at the expense of the market value of the firm. Finally, measurement of acquisition profitability offers minimal measurement error compared to that of investment efficiency, which is generally used as a measure in prior studies. In these studies, a model $^{3}$ is estimated that predicts optimal investment levels and then uses residuals from this model as a proxy for inefficiency. Investment inefficiency is investment that exceeds or lacks the optimal (or expected) level given a firm's investment opportunities. The measurement error caused by assumptions in this model can be used to determine optimal investment size. However, use of acquisition investment profitability as a measure results in fewer measurement errors because market returns which are more reliable are used.

As such, considering the importance of acquisition and the monitoring role of financial reporting quality on management investment decision-making, we expect high-quality financial reporting to be positively associated with a bidder's expected profitability as a result of the acquisition. The first hypothesis is therefore as follows.

H1: High-quality financial reporting is positively associated with acquisition profitability.

Francis and Martin (2010) find that the positive relationship between timely loss recognition and acquisition profitability is more pronounced for firms with high ex ante agency costs. The evidence of their study suggests that since it is costly for outsiders to evaluate management investment decisions and overall firm performance for firms under conditions of greater information asymmetry (Smith and Watts, 1992; Gaver and Gaver, 1993; LaFond and Watts, 2008), financial reporting is an important source of information that allows investors to monitor managers' acquisition investment decisions.

However, the relative importance of financial reporting quality in monitoring acquisition investment decision-making may vary depending on the other sources of information about a firm. Such information may also be obtained from financial analysts. Financial analysts play an integral role as information intermediaries, monitors of corporate performance, and economic agents whose actions affect investors' behavior. Analyst coverage is an important part of a firm's information environment; among other benefits, it may lead to greater investor recognition of a firm (Merton, 1987). Due to the importance of analyst coverage in the information environment, many studies have identified a variety of benefits of analyst coverage, including reduced information asymmetry and increased liquidity (e.g., O'Brien and Bhushan, 1990; Lang and Lundholm, 1996; Frankel and Li, 2004). In addition, the role of analysts in financial markets suggests that they are likely to have a positive influence on firm value by restricting activities of managers that are not geared toward maximizing value (Jensen and Meckling, 1976).

As analysts' activities reduce information asymmetry between managers and outside investors, firms with an analyst following are regarded as having better information environments. Therefore, investors in firms with a

\footnotetext{
3 Traditionally, Tobin's Q model or the modified version of McNichols and Stubben (2008) is used for measurement of investment efficiency in prior studies, as below.

(1) Tobin's Q model

$\mathrm{INV}_{\mathrm{t}}=\alpha_{0}+\beta_{1} \mathrm{Q}_{\mathrm{t}-1}+\beta_{2} \mathrm{CFO}_{\mathrm{t}}+\varepsilon_{\mathrm{t}}$

where:

$\mathrm{INV}=$ Capital expenditures

$=$ Cash outflow from investing activities/Net property, plant, and equipment

$\mathrm{Q}=$ Tobin's $\mathrm{Q}$

$=($ market value of equity + total liabilities $) /$ Book value of total assets

$\mathrm{CFO}=$ Cash flow from operations/Net property, plant, and equipment

(2) modified version of McNichols and Stubben (2008)

$\mathrm{INV}_{\mathrm{t}}=\alpha_{0}+\beta_{1} \mathrm{Q}_{\mathrm{t}-1}+\beta_{2} \mathrm{Q} \_\mathrm{QRT} 2_{\mathrm{t}-1}+\beta_{3} \mathrm{Q}_{-} \mathrm{QRT} 3_{\mathrm{t}-1}+\beta_{4} \mathrm{Q}_{-} \mathrm{QRT}_{\mathrm{t}-1}+\beta_{5} \mathrm{CFO}_{\mathrm{t}}+\beta_{6} \mathrm{GROWTH}_{\mathrm{t}}+\beta_{7} \mathrm{INV}_{\mathrm{t}-1}+\varepsilon_{\mathrm{t}}$

Where:

INV = Capital expenditures

$=$ Cash outflow from investing activities/Net property, plant, and equipment

Q_QRT2 (Q_QRT3, Q_QTR4) = Tobin's Q*, an indicator variable to partition Tobin's Q into quartiles (1 if Q belongs to the second (third, fourth) quartile of its industry-year distribution, and 0 otherwise)

$\mathrm{CFO}=$ Cash flow from operations/Net property, plant, and equipment

Growth $=$ In(total assets/ total assets at the beginning of the year)

Growth $=$ In(total assets/ total assets at the beginning of the year)
} 
good analyst following may depend relatively less on financial reporting quality for information. However, shareholders of firms with no analyst following may depend more on financial reporting. Financial reporting quality is thus likely to play an even more important role in reducing managers' incentives to make unprofitable acquisition investment decisions in such firms. This argument leads to the second hypothesis.

H2: The relative importance of financial reporting quality depends on the characteristics of the information environment.

\section{SAMPLE AND RESEARCH DESIGN}

\subsection{Sample Description}

Our acquisition sample is extracted from the S\&P Capital IQ database. In total, 282 acquisitions made by 150 firms that meet the following criteria are identified between January 1, 2001 and December 31, 2011:

1. The headquarters of the acquiring company is in South Korea.

2. The acquiring company is listed on the Korea Stock Exchange.

3. The acquiring company is not a financial institution.

4. The acquisition is completed at the time of the study.

5. Information about the annual financial statement of the acquiring company is available from the KISVALUE database.

6. Information about the stock return data of the acquiring company is available from the Fn-Guide Database.

Table 1: Sample Distribution

\begin{tabular}{|c|c|c|c|c|c|}
\hline \multicolumn{6}{|c|}{ Panel A: Sample Distribution by Announcement Year } \\
\hline Year & $\begin{array}{c}\text { Number of } \\
\text { Acquisitions }\end{array}$ & $\begin{array}{l}\text { Percentage of } \\
\text { Sample }\end{array}$ & $\begin{array}{c}\text { Median Acquirer Market Value } \\
\text { of Equity (KRW million) }\end{array}$ & $\begin{array}{l}\text { Median Deal Value } \\
\text { (KRW million) }\end{array}$ & $\begin{array}{c}\text { Median Relative } \\
\text { Size }\end{array}$ \\
\hline 2001 & 1 & 0.34 & $11,417,917$ & 15,210 & $0.13 \%$ \\
\hline 2002 & 3 & 1.03 & $11,681,800$ & 53,290 & $5.87 \%$ \\
\hline 2003 & 5 & 1.72 & 155,132 & 5,800 & $2.19 \%$ \\
\hline 2004 & 6 & 2.06 & $8,285,440$ & 53,870 & $8.50 \%$ \\
\hline 2005 & 17 & 5.84 & $1,768,750$ & 17,830 & $4.06 \%$ \\
\hline 2006 & 27 & 10.31 & $1,013,540$ & 21,975 & $3.86 \%$ \\
\hline 2007 & 39 & 14.78 & 695,939 & 11,050 & $2.90 \%$ \\
\hline 2008 & 57 & 20.27 & 209,423 & 10,700 & $6.95 \%$ \\
\hline 2009 & 33 & 11.34 & $4,544,900$ & 66,170 & $4.21 \%$ \\
\hline 2010 & 42 & 14.43 & $4,923,870$ & 61,245 & $1.83 \%$ \\
\hline 2011 & 52 & 17.87 & $1,422,660$ & 8,585 & $1.57 \%$ \\
\hline Total & 282 & 100.00 & $1,341,490$ & 15,210 & $3.13 \%$ \\
\hline \multicolumn{6}{|c|}{ Panel B: Sample Distribution by Industry } \\
\hline \multirow{2}{*}{\multicolumn{3}{|c|}{ Industry Name }} & \multicolumn{2}{|c|}{ Number of Acquisitions } & tage of Sample \\
\hline & & & 12 & \multicolumn{2}{|r|}{$4.26 \%$} \\
\hline \multicolumn{3}{|c|}{ Textile \& Fabric } & 3 & \multicolumn{2}{|r|}{$1.06 \%$} \\
\hline \multicolumn{2}{|c|}{ Pulp \& Paper } & & 4 & \multicolumn{2}{|r|}{$1.42 \%$} \\
\hline \multicolumn{2}{|c|}{ Chemicals } & & 39 & \multicolumn{2}{|r|}{$13.83 \%$} \\
\hline \multicolumn{2}{|c|}{ Non-Metallic Mineral } & & 5 & \multicolumn{2}{|r|}{$1.77 \%$} \\
\hline \multicolumn{2}{|c|}{ Metal } & & 25 & \multicolumn{2}{|r|}{$8.87 \%$} \\
\hline \multicolumn{2}{|c|}{ Transport Equipment } & & 70 & \multicolumn{2}{|r|}{$24.82 \%$} \\
\hline \multicolumn{2}{|c|}{ Electrical Machinery } & & 4 & \multicolumn{2}{|r|}{$1.42 \%$} \\
\hline \multicolumn{2}{|c|}{ General Construction } & & 12 & \multicolumn{2}{|r|}{$4.26 \%$} \\
\hline \multicolumn{2}{|c|}{ Transport } & & 28 & & $9.93 \%$ \\
\hline Service & & & 80 & & $28.37 \%$ \\
\hline Total & & & 282 & & $100.00 \%$ \\
\hline
\end{tabular}

Table 1 presents the summary statistics of the acquisition sample by announcement year. Panel A shows a general increase in the number of acquisitions until 2008, sharp decreases in 2009, and increases again after 2010. Panel A also reports the annual median bidder market value of equity (measured at the end of the fiscal year before 
acquisition), the value of the deal, and the relative size of the deal (defined as the ratio of the value of the deal to the bidder's market value of equity). The median bidder market value is 1,341,490 million Korean won, the median deal value is 15,210 million won, and the median relative deal size is 0.0313 . Panel B provides the industry classification of the bidders in the sample. The most frequent bidders are from service industries $(n=80,28.37 \%)$, followed by those in the transport equipment industry $(\mathrm{n}=70,24.82 \%)$ and the chemical industry $(\mathrm{n}=39,13.83 \%)$.

\subsection{Measure of Financial Reporting Quality}

We use a measure of accruals quality as a proxy for financial reporting quality according to the method of Dechow and Dichev (2002) (hereafter DD) and McNichols (2002). This measure is based on the idea that accruals are adjusted according to the expectation of future cash flows. Therefore, adjusted earnings provide a good measure of firm performance. In the DD model, accruals quality is measured by the extent to which working capital accruals map into operating cash flow realization. DD argue that the quality of accruals and earnings depends on the magnitude of error in estimation of accruals because accruals require assumptions and estimates of future cash flows. As such, DD derive an empirical model of accruals quality as the residuals from regressions of changes in working capital on past, present, and future operating cash flows, as described in Equation (1). The residuals from the regression reflect accruals that are unrelated to cash flow realization.

McNichols (2002) suggests an extension to the model of DD. She finds that the implications of both the DD model and the Jones model (1991) necessitate development of more powerful approaches to the estimation of earnings quality and the role of management discretion in influencing earnings quality. As such, McNichols (2002) suggests a link between the DD model and the Jones model, as described in Equation (2).

DD derive practical measures of accruals quality at the firm-year level in two ways. First of all, DD use the standard deviation of the residuals of firm-level time-series regression as a firm-specific measure of accruals quality, where a higher standard deviation denotes lower quality. However, as Francis et al. (2005) observe, this method has one weakness. If a firm has consistently large residuals resulting in low standard deviations, that firm may seem to have relatively good accruals quality because uncertainty about its accruals is low, even if in reality, the accruals map poorly into cash flows. Thus, DD develop an alternative measure of accruals quality at the firm-year level using the absolute value of the residuals ${ }^{4}$ for that year, which is estimated cross-sectionally. We use this alternative measure in this study. We estimate the model in Equations (1) and (2) cross-sectionally for each industry with at least 10 observations in a given year based on each firm's KIS-VALUE industry middle-classification.

We multiply absolute residuals from Equations (1) and (2) by -1 so that this variable increases as financial reporting quality increases, as described in Equation (3). All variables are scaled by total assets.

$\Delta \mathrm{WC}_{\mathrm{i}, \mathrm{t}}=\beta_{0}+\beta_{1}$ CashFlow $_{\mathrm{i}, \mathrm{t}-1}+\beta_{2}$ CashFlow $_{\mathrm{i}, \mathrm{t}}+\beta_{3}$ CashFlow $_{\mathrm{i}, \mathrm{t}+1}+\varepsilon_{\mathrm{i}, \mathrm{t}}$

$\Delta \mathrm{WC}_{\mathrm{i}, \mathrm{t}}=\beta_{0}+\beta_{1}$ CashFlow $_{\mathrm{i}, \mathrm{t}-1}+\beta_{2}$ CashFlow $_{\mathrm{i}, \mathrm{t}}+\beta_{3}$ CashFlow $_{\mathrm{i}, \mathrm{t}+1}+\beta_{4} \Delta$ Sales $_{\mathrm{i}, \mathrm{t}}+\beta_{5} \mathrm{PPE}_{\mathrm{i}, \mathrm{t}}+\varepsilon_{\mathrm{i}, \mathrm{t}}$

where:

$\Delta \mathrm{WC}=(\Delta \mathrm{CA}-\Delta \mathrm{Cash})-(\Delta \mathrm{CL}-\Delta \mathrm{STD})$

$\triangle \mathrm{CA}=$ Change in current assets

$\Delta$ Cash $=$ Change in cash and cash equivalents

$\Delta \mathrm{CL}=$ Change in current liabilities

$\triangle \mathrm{STD}=$ Change in short - term debt

CashFlow $=$ cash from operations from the statement of cash flow

$\Delta$ Sales $=$ change in sales

$\mathrm{PPE}=$ Gross property, plant and equipment

\footnotetext{
${ }^{4}$ This measure is highly correlated with the standard deviation of the residuals of time-series regression. 
$\mathrm{AQ}_{\mathrm{i}, \mathrm{t}}=(-1) *\left|\varepsilon_{\mathrm{i}, \mathrm{t}}\right|$

where:

$\mathrm{AQ}=$ Accruals quality

$\varepsilon=$ residual from Equation (1) or Equation (2)

\subsection{Measure of Expected Acquisition Profitability}

We measure acquisition profitability by market-adjusted stock returns of bidders around the time of initial announcement of an acquisition, since the market reaction around this time captures both the ex ante investment selection and the expected value of ex post decision-making. Announcement dates are obtained from the S\&P Capital IQ database. We compute an acquirer's 3-day cumulative abnormal return (AcqCAR) centered on the acquisition announcement date. The KOSPI value-weighted return ${ }^{5}$ is used for market return.

\subsection{Empirical Models}

We examine the association between high-quality financial reporting and acquisition profitability in our testing of hypothesis 1 . As such, we test $\mathrm{H} 1$ with additional firm acquisition-level controls in the following model:

AcqCAR $_{\mathrm{i}, \mathrm{t}}=\beta_{1}+\beta_{2} \mathrm{AQ}_{\mathrm{i}, \mathrm{t}-1}+\beta_{3}$ Size $_{\mathrm{i}, \mathrm{t}}+\beta_{4}$ Leverage $_{\mathrm{i}, \mathrm{t}}+\beta_{5}$ TobinQ $_{\mathrm{i}, \mathrm{t}}+\beta_{6} \operatorname{Loss}_{\mathrm{i}, \mathrm{t}}+\beta_{7}$ RelativeSize $_{\mathrm{i}, \mathrm{t}}+$ $\beta_{8}$ Stockdeal $_{\mathrm{i}, \mathrm{t}} \beta_{9}$ Interest $_{\mathrm{i}, \mathrm{t}}+\beta_{10}$ Chaebol $_{\mathrm{i}, \mathrm{t}}+$ YearDummy IndustryDummy $+\varepsilon_{\mathrm{i}, \mathrm{t}}$

The dependent variable, acquisition profitability (AcqCAR), is examined using 3-day CAR around the time of initial acquisition announcement. The independent variable, accruals quality (AQ), is used as a proxy for financial reporting quality in its form from both the DD model (hereafter AQ1) and the model suggested by McNichols (2002) (hereafter AQ2), as discussed in section 3.2.

We consider four control variables for bidder characteristics, three control variables for deal characteristics, one control variable for the unique aspects of Korean corporate governance, and year and industry controls, which are related to acquirer returns in Equation (4). Bidder traits, including firm size (Size), leverage (Leverage), Tobin's $\mathrm{q}$ (TobinQ), and past firm performance (Loss) are also controlled. Deal characteristics including relative deal value (RelativeSize), method of payment (Stockdeal), and ownership due to acquisition (Interest) are also controlled. Finally, we control for the unique Korean form of corporate governance known as the Chaebol (Chaebol), which identifies the bidder as a member or nonmember of a Korean business group.

Moeller, Schlingemann, and Stulz (2004) find a negative correlation between bidder size and the bidder's CAR during the announcement period. They find that on average, larger acquirers pay higher premiums and make acquisitions that generate negative synergies. This finding supports the managerial hubris hypothesis (Roll, 1986). Also, since larger firms have more effective takeover mechanisms, managers of large firms are more entrenched and more likely to make value-decreasing acquisitions. In our test, we define firm size as the log transformation of the bidder's total assets.

Leverage is an important governance mechanism, since creditors have significant control over managers and power to limit managerial discretion. Leverage also provides incentives for managers to improve firm performance, because if their firms fall into financial distress, they may lose their jobs. As such, we control for leverage in the model, measuring it as total liability divided by total equity.

Prior studies find that the Tobin's q value of an acquirer has an ambiguous effect on CAR. Lang, Stulz, and Walking (1991) and Servas (1991) document a positive association between Tobin's q and tender offer acquisitions and public firm acquisitions, respectively, while Moeller, Schlingemann, and Stulz (2004) find a negative association in a comprehensive sample of acquisitions. We define Tobin's $q$ as the ratio of a bidder's market value of

${ }^{5}$ Using equally-weighted return as market return has same results. 
assets over its book value of assets, where market value of assets is computed as the book value of assets minus the book value of common equity plus the market value of common equity.

According to Lakonishok and Shleifer Vishny (1994) and Hayward and Hambrick (1995), past firm performance influences acquisition decision-making, especially for managers of firms with poor performance, who must be prudent with their investments. As such, we control for past performance by including a dummy variable coded as 1 if the bidder's net income is $<0$, and 0 otherwise.

We also control for relative deal size. Asquith, Bruner, and Mullins (1983) find that bidder announcement returns increase relative to deal size, and the reverse is also true for the subsample of large bidders in Moeller, Schlingemann, and Stulz (2004). We measure relative deal size as the deal value divided by the bidder's market value measured at the fiscal year-end prior to the announcement of acquisitions. We also consider the method of payment as a control variable. According to Servaea (1991) and Brown and Ryngaert (1991), bidders experience significantly negative abnormal returns on the announcement date when they pay for acquisitions with equity, but not when they pay with cash. In order to capture the effects of the deal payment method, we include an indicator variable denoted by stock deal, where stock deal $=1$ for acquisitions financed either partially or fully with stock, and 0 otherwise. As the acquirer's ownership after acquisition has an effect on investment profitability (Park and Lee, 2006; Jung and Park, 2006), we also control for ownership ratio after the deal.

Additionally, we control for the unique form of Korean corporate governance called the Chaebol (or business group). Jung et al. (2002) and An et al. (2002) state that majority shareholders have sufficient ownership and rights to govern management decisions in Korea. Chaebol is a dummy variable coded as 1 if the bidder belongs to a business group, and 0 otherwise. Finally, we include year and industry dummies in the regression model as control variables.

\section{RESULTS}

\subsection{Descriptive Statistics}

Panel A of Table 2 lists descriptive statistics for the full sample. The mean (median) 3-day bidder CAR (AcqCAR) is $1.48 \%(0.77 \%)$, which is slightly higher than the mean of $1.2 \%$ and median of $0.4 \%$ reported in Francis and Martin (2010). The mean and median values for accruals quality (AQ1) during the year before acquisition are -0.0739 and -0.041 , respectively. These statistics are higher than the mean of -0.107 and median of -0.077 reported in Kim et al. (2010). This means that firms that make investments in the form of acquisitions have higher-quality reporting on average than firms that do not. Values for the other measure of accruals quality, AQ2, are similar to those for AQ1. The leverage for the average (median) acquirer in our sample is $1.1754(0.9365)$. The Tobin's q for the average (median) acquirer in our sample is 1.3273 (1.1450). The mean of Loss is 0.1454 , which shows that for $14.54 \%$ of the bidders, net income is $<0$. The relative deal size (the deal value scaled by the bidder's market value) for the average (median) acquirer in our sample is $0.1419(0.0266)$, which shows that $14.19 \%$ of the equity value of the bidders is used to pay for the deal on average. The mean value for the stock deal dummy is 0.1206 , indicating that $12.06 \%$ of the payments made for acquisition in this sample are financed either partially or fully with stock. The mean of Interest is 0.5113 , which shows that the bidder acquires $51.03 \%$ interest in the target's shares after acquisition on average. The mean of the Chaebol dummy is 0.6560 , indicating that $65.60 \%$ of the acquirers belong to a Korean business group.

Panel B shows descriptive statistics only for firms with analyst followings. In this sample, 171 acquisitionfirm observations are included. In addition, for 111 acquisition-firm observations, the firms have no analyst following. These are reported in Panel C. Financial reporting quality is higher for firms with analyst following than firms with no analyst following, as indicated by the mean (median) of AQ1 of $-0.0523(-0.0344)$ and the mean (median) of AQ2 of -0.0541 ( -0.0364$)$ for firms with analyst following, and the mean (median) of AQ1 of -0.1071 $(-0.0611)$ and the mean (median) of AQ2 of $-0.0990(-0.0587)$ for firms with no analyst following. Firms with analyst following are larger in size than firms with no analyst following on average, as indicated by the mean of the $\log$ transformation of the bidder's total assets for firms with analyst following of 29.0244, and that for firms with no analyst following of 26.9103. Bidders with no analyst following (mean loss: $30.63 \%$ ) lost more net income than 
bidders with analyst following (mean loss: 4.09\%) on average. Firms with no analyst following make bigger acquisition investments relative to their equity value than firms with analyst following, as indicated by the mean (median) of RelativeSize for firms with no analyst following of 0.1905 (0.0606) and the mean (median) of RelativeSize for firms with analyst following of 0.1104 (0.0148). In addition, for $16.96 \%$ of the sample of acquiring firms with analyst following, the acquisitions are financed either partially or fully with stock, but this is true for only $4.51 \%$ of the sample of acquiring firms with no analyst following. Finally, firms with analyst following belong to a Korean business group (Chaebol) more often than firms with no analyst following (80.70\% vs. $42.34 \%$ ).

Table 2: Summary Statistics

\begin{tabular}{lcccccc}
\hline Panel A: Full Sample & & & & & & \\
\hline \multicolumn{1}{c}{ Variable } & N & Mean & StdDev & Minimum & Median & Maximum \\
\hline AcqCAR(VWI) & 282 & 0.0148 & 0.0671 & -0.2811 & 0.0077 & 0.4375 \\
AQ1 & 282 & -0.0739 & 0.0977 & -0.7007 & -0.0411 & -0.0004 \\
AQ2 & 282 & -0.0718 & 0.0913 & -0.6244 & -0.0426 & -0.0003 \\
Size & 282 & 28.1923 & 2.1318 & 24.0235 & 28.3559 & 32.3971 \\
Leverage & 282 & 1.1754 & 1.2139 & 0.0354 & 0.9365 & 10.2233 \\
TobinQ & 282 & 1.3273 & 0.9168 & 0.4803 & 1.1450 & 6.5566 \\
Loss & 282 & 0.1454 & 0.3531 & 0.0000 & 0 & 1.0000 \\
RelativeSize & 282 & 0.1419 & 0.3269 & 0.0000 & 0.0266 & 1.9542 \\
Stock deal & 282 & 0.1206 & 0.3262 & 0.0000 & 0 & 1.0000 \\
Interest & 282 & 0.5113 & 0.3483 & 0.0115 & 0.4900 & 1.0000 \\
Chaebol & 282 & 0.6560 & 0.4759 & 0.0000 & 1 & 1.0000 \\
\hline
\end{tabular}

AcqCAR is 3-day market adjusted cumulative stock returns of bidders around the time of initial acquisition announcement $(-1,+1)$. AQ1 is financial reporting quality measured by Dechow and Dichev (2002). AQ2 is financial reporting quality measured by McNichols (2002). Size is the natural logarithm of assets at the beginning of the fiscal year. Leverage is the book value of debt scaled by the total book value of equity. TobinQ is the ratio of a bidder's market value of assets over its book value of assets, where market value of assets is computed as the book value of assets minus the book value of common equity plus the market value of common equity. Loss is a dummy variable coded as 1 if the bidder has net income below 0 , and 0 otherwise. RelativeSize is equal to deal value divided by bidder's market value measured at the fiscal year-end prior to acquisition announcement. Stock deal is a dummy variable coded as 1 if acquisitions are financed either partially or fully by stock, and 0 otherwise. Interest is the bidder's interest of the target's shares of the acquisition. Chaebol is a dummy variable coded as 1 if the bidder belongs to a business group, and 0 otherwise.

\begin{tabular}{|c|c|c|c|c|c|c|}
\hline \multicolumn{7}{|c|}{ Panel B: $\quad$ Firms with Analyst Followings } \\
\hline Variable & $\mathbf{N}$ & Mean & StdDev & Minimum & Median & Maximum \\
\hline AcqCAR & 171 & 0.0109 & 0.0516 & -0.1126 & 0.0066 & 0.1974 \\
\hline AQ1 & 171 & -0.0523 & 0.0602 & -0.4690 & -0.0344 & -0.0008 \\
\hline AQ2 & 171 & -0.0541 & 0.0607 & -0.4791 & -0.0364 & -0.0009 \\
\hline Size & 171 & 29.0244 & 1.6413 & 24.9051 & 29.0825 & 32.3055 \\
\hline Leverage & 171 & 1.1800 & 1.2634 & 0.1859 & 0.8651 & 10.2233 \\
\hline TobinQ & 171 & 1.4950 & 1.0996 & 0.4803 & 1.1951 & 6.5566 \\
\hline Loss & 171 & 0.0409 & 0.1987 & 0.0000 & 0.0000 & 1.0000 \\
\hline RelativeSize & 171 & 0.1104 & 0.2990 & 0.0001 & 0.0148 & 1.9542 \\
\hline Stock deal & 171 & 0.1696 & 0.3764 & 0.0000 & 0.0000 & 1.0000 \\
\hline Interest & 171 & 0.5350 & 0.3520 & 0.0115 & 0.5000 & 1.0000 \\
\hline Chaebol & 171 & 0.8070 & 0.3958 & 0.0000 & 1.0000 & 1.0000 \\
\hline \multicolumn{7}{|c|}{ This table presents descriptive statistics only for the firms with analyst following. All variables are defined in Panel A of Table 2.} \\
\hline \multicolumn{7}{|c|}{ Panel C: Firms without Analyst Followings } \\
\hline Variable & $\mathbf{N}$ & Mean & StdDev & Minimum & Median & Maximum \\
\hline AcqCAR & 111 & 0.0208 & 0.0855 & -0.2811 & 0.0092 & 0.4375 \\
\hline AQ1 & 111 & -0.1071 & 0.1301 & -0.7007 & -0.0611 & -0.0004 \\
\hline AQ2 & 111 & -0.0990 & 0.1199 & -0.6244 & -0.0587 & -0.0003 \\
\hline Size & 111 & 26.9103 & 2.1705 & 24.0235 & 26.3585 & 32.3971 \\
\hline Leverage & 111 & 1.1685 & 1.1389 & 0.0354 & 0.9868 & 8.3687 \\
\hline TobinQ & 111 & 1.0690 & 0.4093 & 0.4803 & 0.9767 & 2.7359 \\
\hline Loss & 111 & 0.3063 & 0.4631 & 0.0000 & 0.0000 & 1.0000 \\
\hline RelativeSize & 111 & 0.1905 & 0.3619 & 0.0000 & 0.0606 & 1.9542 \\
\hline Stock deal & 111 & 0.0451 & 0.2083 & 0.0000 & 0.0000 & 1.0000 \\
\hline Interest & 111 & 0.4748 & 0.3411 & 0.0115 & 0.4496 & 1.0000 \\
\hline Chaebol & 111 & 0.4234 & 0.4963 & 0.0000 & 1.0000 & 1.0000 \\
\hline
\end{tabular}

This table presents descriptive statistics only for the firms with no analyst following. All variables are defined in Panel A of Table 2. 
Table 3 presents Pearson correlations. The market perceives acquisitions to be more profitable when bidders have higher leverage, less loss of income, higher-value deals, and deals that are financed partially or fully with stock. A positive relationship is evident between financial reporting quality (AQ1 and AQ2) and firm size (Size), and between financial reporting quality and membership in a Korean business group (Chaebol). However, a negative relationship is evident between financial reporting quality and Leverage, Loss, and RelativeSize.

Table 3: Pearson Correlation Matrix

\begin{tabular}{|c|c|c|c|c|c|c|c|c|c|c|}
\hline & AQ1 & $\mathbf{A Q 2}$ & SIZE & Leverage & TobinQ & Loss & $\begin{array}{c}\text { Relative } \\
\text { Size } \\
\end{array}$ & Stockdeal & Interest & Chaebol \\
\hline AcqCAR & 0.040 & 0.033 & -0.095 & $0.155^{* * *}$ & -0.024 & $0.141 * *$ & $0.113^{*}$ & $0.109 *$ & 0.041 & -0.041 \\
\hline AQ1 & & $0.945^{* * *}$ & $0.511 * * *$ & $-0.103^{*}$ & 0.052 & $-0.392 * * *$ & $-0.145^{* *}$ & -0.004 & -0.046 & $0.399 * * *$ \\
\hline AQ2 & & & $0.500 * * *$ & $-0.126^{* *}$ & 0.013 & $-0.350 * * *$ & $-0.111^{*}$ & -0.028 & -0.0709 & $0.395 * * *$ \\
\hline SIZE & & & & 0.025 & 0.007 & $-0.474 * * *$ & $-0.258 * * *$ & -0.017 & $-0.245 * * *$ & $0.772 * * *$ \\
\hline Leverage & & & & & -0.040 & $0.122 * *$ & $0.131^{* *} *$ & 0.009 & $-0.107 *$ & $0.149 * *$ \\
\hline TobinQ & & & & & & -0.068 & $-0.132 * *$ & -0.036 & $0.206^{* * * *}$ & -0.030 \\
\hline Loss & & & & & & & 0.089 & -0.029 & 0.092 & $-0.421 * * *$ \\
\hline $\begin{array}{l}\text { Relative } \\
\text { Size }\end{array}$ & & & & & & & & $0.129 * *$ & 0.082 & $-0.106^{*}$ \\
\hline Stockdeal & & & & & & & & & $0.2271^{* * * *}$ & -0.0299 \\
\hline Interest & & & & & & & & & & $-0.2305^{* * * *}$ \\
\hline
\end{tabular}

All variables are defined in Panel A of Table 2.

\subsection{Main Results}

Table 4 reports the results of the multivariate test of the hypotheses based on the estimation in Equation (4). Columns 2 and 3 present the regression results using accruals quality from the DD model (AQ1) as the independent variable, and Columns 4 and 5 report the results using the independent variable from the McNichols model (AQ2). As predicted in hypothesis 1, the results show that the coefficients of both AQ1 and AQ2 on AcqCAR are positive and significant at the $10 \%$ level. These results suggest that firms with high-quality financial reporting make more profitable acquisitions based on ex ante perceptions. In addition, as financial reporting quality plays a monitoring role in the management of acquisition investment, high-quality financial reporting leads to acquisition efficiency. With respect to the control variables, only the coefficients for AcqCAR of leverage and Loss are positive and statistically significant when AQ1 is used as the independent variable.

Table 4: OLS Regression Analysis of the Association between Bidder Announcement Returns and Financial Reporting Quality

$\operatorname{AcqCAR}_{\mathrm{i}, \mathrm{t}}=\beta_{1}+\beta_{2} \mathrm{AQ}_{\mathrm{i}, \mathrm{t}-1}+\beta_{3}$ Size $_{\mathrm{i}, \mathrm{t}}+\beta_{4}$ Leverage $_{\mathrm{i}, \mathrm{t}}+\beta_{5}$ TobinQ $_{\mathrm{i}, \mathrm{t}}+\beta_{6}$ Loss $_{\mathrm{i}, \mathrm{t}}+\beta_{7}$ RelativeSize $_{\mathrm{i}, \mathrm{t}}+\beta_{8}$ Stockdeal $_{\mathrm{i}, \mathrm{t}}+\beta_{9}$ Interest $_{\mathrm{i}, \mathrm{t}}+$ $\beta_{10}$ Chaebol $_{i, t}+$ YearDummy + IndustryDummy $+\varepsilon_{i, t}$

\begin{tabular}{|c|c|c|c|c|}
\hline \multirow{2}{*}{ Variable } & \multicolumn{2}{|c|}{ Independent Variable: AQ1 } & \multicolumn{2}{|c|}{ Independent Variable: AQ2 } \\
\hline & Coeff. & t Value & Coeff. & t Value \\
\hline Intercept & 0.034 & 0.35 & 0.030 & 0.31 \\
\hline $\mathrm{AQ}$ & 0.090 & $1.83^{*}$ & 0.092 & $1.75 *$ \\
\hline Size & -0.002 & -0.56 & -0.002 & -0.52 \\
\hline Leverage & 0.005 & $1.44 *$ & 0.006 & 1.51 \\
\hline TobinQ & 0.002 & 0.35 & 0.002 & 0.43 \\
\hline Loss & 0.031 & $2.29 * *$ & 0.029 & 2.19 \\
\hline RelativeSize & 0.012 & 0.93 & 0.011 & 0.84 \\
\hline Stock deal & 0.018 & 1.47 & 0.019 & 1.52 \\
\hline Interest & -0.007 & -0.52 & -0.006 & -0.48 \\
\hline Chaebol & 0.009 & 0.62 & 0.009 & 0.61 \\
\hline Year dummy & \multicolumn{2}{|c|}{ Include } & \multicolumn{2}{|c|}{ Include } \\
\hline Industry dummy & \multicolumn{2}{|c|}{ Include } & \multicolumn{2}{|c|}{ Include } \\
\hline $\mathrm{N}$ & \multicolumn{2}{|c|}{282} & \multicolumn{2}{|c|}{282} \\
\hline $\operatorname{Adj}-R^{2}(\%)$ & \multicolumn{2}{|c|}{$11.07 \%$} & \multicolumn{2}{|c|}{$10.98 \%$} \\
\hline
\end{tabular}

All variables are defined in Panel A of Table 2. *** indicates significance at the $1 \%$ level, ** at the 5\% level, and * at the $10 \%$ level.

Hypothesis 2 posits a weaker positive association between financial reporting quality and acquisition efficiency in good information environments or for firms with good analyst following. In other words, the effect of 
financial reporting on acquisition efficiency is more important in low-quality information environments. Table 5 presents the results of testing of Hypothesis 2. Panel A presents the association between bidder returns and financial reporting quality for firms with analyst following. In this sample, financial reporting quality is unrelated to acquisition profitability. However, Panel B shows a positive association between financial reporting quality and acquisition efficiency for firms with no analyst following. The coefficient of AQ1 is positive and significant at the $1 \%$ level, and the coefficient of AQ2 is also positive and significant at the $10 \%$ level. This result is consistent with our prediction, and suggests that financial reporting quality is more important to the control of management acquisition decision-making in poor information environments. In addition, financial reporting quality and existing information environment are substitutes in terms of the association with acquisition investment efficiency.

Table 5: Analyst Following and the Association of Bidder Returns and Financial Reporting Quality

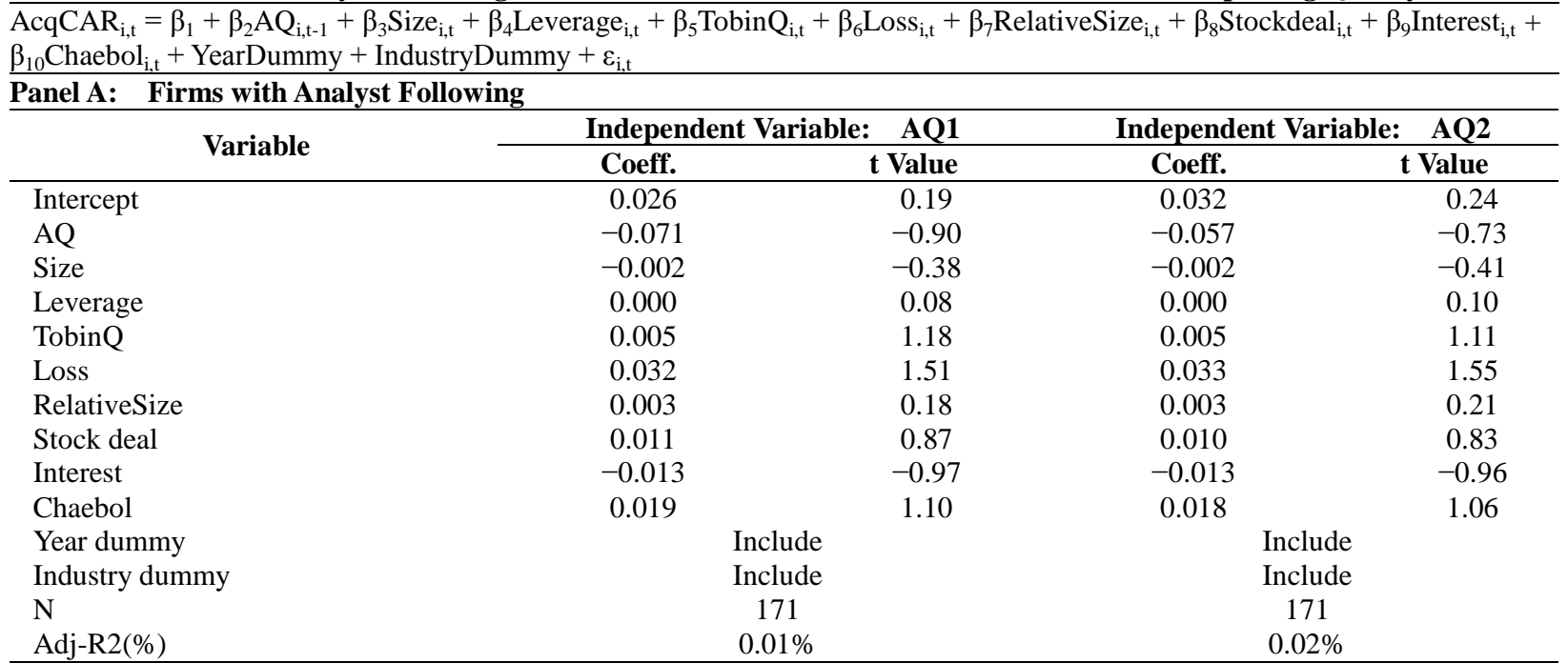

All variables are defined in Panel A of Table $2 . * * *, * *, *$ indicates significance at the $1 \%, 5 \%$, and $10 \%$ level, respectively.

Panel B: $\quad$ Firms without Analyst Following

\begin{tabular}{|c|c|c|c|c|}
\hline \multirow{2}{*}{ Variable } & \multicolumn{2}{|c|}{ Independent Variable: $\mathrm{AQ1}$} & \multirow{2}{*}{\multicolumn{2}{|c|}{ Independent Variable: $\mathrm{AQ}^{2}$}} \\
\hline & Coeff. & t Value & & \\
\hline Intercept & 0.034 & 0.19 & 0.005 & 0.03 \\
\hline $\mathrm{AQ}$ & 0.203 & $2.67 * * *$ & 0.184 & $2.22 *$ \\
\hline Size & -0.001 & -0.18 & 0.000 & -0.04 \\
\hline Leverage & -0.008 & -0.94 & -0.007 & -0.75 \\
\hline TobinQ & 0.012 & 0.56 & 0.011 & 0.52 \\
\hline Loss & 0.027 & 1.22 & 0.023 & 1.04 \\
\hline RelativeSize & -0.011 & -0.40 & -0.013 & -0.46 \\
\hline Stock deal & 0.077 & $1.91 *$ & 0.078 & $1.89 * *$ \\
\hline Interest & -0.006 & -0.25 & -0.003 & -0.10 \\
\hline Chaebol & 0.000 & 0.00 & -0.002 & -0.09 \\
\hline Year dummy & \multicolumn{2}{|c|}{ include } & \multicolumn{2}{|c|}{ Include } \\
\hline Industry dummy & \multicolumn{2}{|c|}{ include } & \multicolumn{2}{|c|}{ Include } \\
\hline $\mathrm{N}$ & \multicolumn{2}{|c|}{111} & \multicolumn{2}{|c|}{111} \\
\hline $\operatorname{Adj}-\mathrm{R} 2(\%)$ & \multicolumn{2}{|c|}{$21.96 \%$} & \multicolumn{2}{|c|}{$30.27 \%$} \\
\hline
\end{tabular}

All variables are defined in Panel A of Table 2. ***, **, * indicates significance at the 1\%, 5\%, and 10\% level, respectively.

Overall, the results in Tables 4 and 5 support $\mathrm{H} 1$ and $\mathrm{H} 2$. Thus, because financial reporting quality plays a monitoring role in management acquisition investment, higher-quality financial reporting leads to greater acquisition efficiency. In addition, since elements of the information environment, such as financial analyst following, could be substitutes of financial reporting, the positive association between high-quality financial reporting and acquisition profitability is weakened for firms in good information environments. This provides further support for the assertion that financial reporting quality is more important for firms in poor information environments. 


\section{SUMMARY AND CONCLUSION}

In this study, we investigate the association between financial reporting quality and firm decision-making regarding investment in the form of acquisition. We find that firms with higher-quality accounting make more profitable acquisitions, as evidenced by ex ante market perceptions (larger announcement returns measured by 3-day CAR). Our results suggest that firms with higher-quality accounting are less likely to make myopic acquisition investment decisions. For these firms, financial accounting reporting quality acts as an effective monitoring mechanism to control managers' opportunistic behavior when making acquisition investment decisions. We also find that the association between financial reporting quality and acquisition profitability is more salient for firms with poor information environments and no analyst following. The results of the analysis show that the effect of financial reporting quality on acquisition profitability is more important for firms in poor information environments. This result suggests that financial reporting quality and information environment have similar effects on acquisition investment efficiency.

Overall, the evidence provided in this study is consistent with the findings in extant accounting literature, which shows that financial reporting quality is a useful monitoring tool for firms to address agency problems and improve the efficiency of their acquisition investments.

\section{AUTHOR INFORMATION}

Youngtae Yoo, Ph.D., School of Business, Yonsei University, 134 Shinchon-dong, Seodaemoon-gu, Seoul 120-749, Korea. E-mail: ytae@yonsei.ac.kr

Joohyun Lim, Ph.D. Candidate of Business Administration, School of Business, Yonsei University, 134 Shinchondong, Seodaemoon-gu, Seoul 120-749, Korea. E-mail: joohyun_lim@yonsei.ac.kr (Corresponding author)

Jinho Chang, Ph.D., Professor of Business Administration, School of Business, Yonsei University, 134 Shinchondong, Seodaemoon-gu, Seoul 120-749, Korea. E-mail: chang@yonsei.ac.kr

\section{REFERENCES}

1. An, H., Choi K. and Song, J., 2002. Ownership Structure and the Inforrmativeness of Accounting Earnings, Korean Accounting Review 27(4): 1-30.

2. Asquith, Paul, Robert F. Bruner, and David W. Mullins, Jr., 1983, The gains to bidding firms from merger, Journal of Financial Economics 11: 121-139.

3. Ball, R., 1989. The Firms as a Specialist Contracting Intermediary: Application to Accounting and Auditing. University of Chicago, Chicago.

4. Beatty, A., Liao, S., Weber, J., 2008. Financial reporting quality, private information, monitoring and the lease-versus-buy decision. Working Paper, Ohio State University.

5. Bens, D., and S. Monahan, 2004. Disclosure quality and the excess value of diversification. Journal of Accounting Research 42(4): 691-730.

6. Berle, Adolph A., and Gardiner C. Means, 1933. The Modern Corporation and Private Property (Macmillian, New York).

7. Biddle, G. and G. Hilary. 2006. Accounting Quality and Firm-Level Capital Investment. The Accounting Review 31: 963-982.

8. Biddle, G., G. Hilary, and R. Verdi. 2009. How does Financial Reporting Quality relate to Investment Efficiency? Journal of Accounting and Economics 48: 112-131.

9. Blanchard, O., F. Lopez-de-Silanes, and A. Shleifer, 1994. What do firms do with cash windfalls? Journal of Financial Economics 36: 337-360.

10. Brown, David T., and Michael D. Ryngaert, 1991, The mode of acquisition in takeovers: Taxes and asymmetric information, Journal of Finance 46: 653-669.

11. Bushman, R., and A. Smith, 2001. Financial accounting information and corporate governance. Journal of Accounting and Economics 31: 237-333. 
12. Bushman, R., Piotroski, J., Smith, A., 2006. Capital allocation and timely accounting recognition of economic losses: international evidence. Working Paper, University of Chicago.

13. Chang, X., S. Dasgupta, and G. Hillary, 2009, The effect of auditor quality on financing decisions, The Accounting Review 84: 1085-1117.

14. Chen, X., Harford, J., Kai, L., 2007. Monitoring: Which institutions matter?. Journal of Financial Economics 86: 279-305.

15. Dechow, P., and I. Dichev, 2002. The quality of accruals and earnings: the role of accrual estimation error. The Accounting Review 77, Supplement: 35-59.

16. Francis, J., R. LaFond, P. Olsson, and K. Schipper, 2005. The market pricing of accruals quality. Journal of Accounting and Economics 39(2): 295-327.

17. Frankel, R., Li, X., 2004. Characteristics of a Firm's Information Environment and the Information Asymmetry between Insiders and Outsiders. Journal of Accounting and Economics 37: 229-259.

18. Francis, R. and X. Martin. 2010. Acquisition profitability and timely loss recognition. Journal of Accounting and Economics 49: 161-178.

19. Garver, J. Garver, K., 1993. Additional evidence on the association between the investment opportunity set and corporate financing, dividend, and compensation policies. Journal of Accounting and Economics 16: 125-160.

20. Healy, P., and K. Palepu, 2001. Information asymmetry, corporate disclosure, and the capital markets: A review of the empirical disclosure literature. Journal of Accounting and Economics 31(1-3): 405-440.

21. Hope, O., Thomas, W., 2008. Managerial empire building and firm disclosure. Journal of Accounting Research 46: 591-626.

22. Hayward, M. L. A. and D. C. Hambrick, 1997, Explaining Premiums Paid for Large Acquisition: Evidence of CEO Hubris, Administrative Science Quarterly 42: 103-127.

23. Jensen, Michael C., 1986, Agency costs of free cash flow, corporate finance, and takeovers. American Economic Review 76: 323-329.

24. Jensen, M., 2000. Modern Industrial Revolution, Exit and the Failure of Internal Control Systems. Harvard University Press.

25. Jensen, M., Meckling, W., 1976. The theory of the firm: managerial behavior, agency costs, and ownership structure. Journal of Financial Economics 3: 305-360.

26. Jensen, Michael C., and William H. Meckling, 1976. Theory of the firm: Managerial behavior, agency costs, and ownership structure, Journal of Financial Economics 3: 305-360.

27. Jones, J. J. 1991. Earnings management during import relief investigation. Journal of Accounting Research 29: 193-228.

28. Jung, K., S. Kwon, and W. Paek. 2002. Ownership Structure and Earnings Informativeness: Evidence from Korea, Korean Management Review 31(6): 1707-1727.

29. Jung, T., and Park, J. 2006. Do Firms' Cross-border Acquisitions Decrease Shareholder Wealth?: With Emphasis on Survival Strategy Hypothesis, Reverse-internalization Hypothesis, and Multinational Network Hypothesis, Korean Management Review 35 1075-1104

30. Kim, J., H. Paik, J. Goh. 2010. The effect of accrual quality and analysts' information environments on analysts' forecast accuracy. Korean Accounting Review 35(3): 1-35.

31. LaFond, R., Watts, R., 2008. The information role of conservative financial statements. The Accounting Review 83: 447-478.

32. Lakonishok, J., Shleifer, A. and R. W. Vishny 1994, Constrain Investment Extrapolation, and Risk, Journal of Finance, 49(5), 1541-1578.

33. Lang, Larry H. P., Ren'e M. Stulz, and Ralph A. Walkling, 1991, A test of the free cash flow hypothesis: The case of bidder returns, Journal of Financial Economics 29: 315-336.

34. Lang, M., Lundholm, R., 1996. Corporate disclosure policy and analyst behavior. The Accounting Review 71: 467-492.

35. McNichols, M., 2002. Discussion of the quality of accruals and earnings: the role of accrual estimation errors. The Accounting Review 77: 61-69.

36. McNichols. M., and S. Stubben, 2008. Does earnings management affect firms' investment decisions? The Accounting Review 83: 1571-1603.

37. McNichols. M., and S. Stubben, 2011, The effect of target-firm accounting quality on valuation in acquisition, Working paper. 
38. Merton, R.C., 1987. A simple model of capital market equilibrium with incomplete information. Journal of Finance 42: 483-510.

39. Moeller, Sara B., Frederik P. Schlingemann, and Ren'e M. Stulz, 2004, Firm size and the gains from acquisitions, Journal of Financial Economics 73: 201-228.

40. Morck, Randall, Andrei Shleifer, and Robert W. Vishny, 1990. Do managerial incentives drive bad acquisitions? Journal of Finance 45: 31-48.

41. Myers, Stewart C., and Nicholas S. Majluf, 1984. Corporate financing and investment decisions. when firms have information that investors do not have. Journal of Financial Economics 13: 187-221.

42. O'Brien, P., Bhushan, R., 1990. Analyst following and institutional holding. Journal of Accounting Research: 55-76.

43. Park, J., and Lee, J., 2006. Post-Merger and Acquisition the Long-run Performance of Korean Acquiring Firms. Korean Journal of Business Administration. 19(5) 1781-1801.

44. Raman, K., L. Shivakumar, and A. Tamayo, 2008, Targets' earnings quality and bidders' takeover decisions, Working paper.

45. Roll, Richard, 1986, The hubris hypothesis of corporate takeovers, Journal of Business 59: 197-216.

46. Servaes, Henri, 1991, Tobin's q and the gains from takeover, Journal of Finance 46: 409-419.

47. Shleifer, Andrei, and Robert W. Vishny, 1989, Managerial entrenchment: The case of manager-specific investment. Journal of Financial Economics 25: 123-140.

48. Smith, C., Watts, R., 1992. The investment opportunity set and corporate financing, dividend and compensation policies. Journal of Financial Economics 32: 263-292.

49. Watts, R., Zimmerman, J., 1983. Agency problems, auditing, and the theory of the firm: some evidence. Journal of Financial Economics 26: 613-634.NJ 